\title{
Immunostimulant Effect of Garlic Chives Leaf Ethanolic Extract (Allium tuberosum) by Increasing Level of Antioxidant at Rats Doxorubicin-Induced Rats
}

\author{
Ika Rahmawati Sutejo*, Kiky Martha Ariesaka, Fuad Adi Prasetyo, Mudzakkir \\ Taufiqurrahman, Ain Yuanita Insani, Brilliant Givya Ariansari
}

Faculty of Medicine, Universitas Jember, Jember, Indonesia

\begin{abstract}
Cancer is one of the leading causes of death in the world, approximately 14 million new cases and 8.2 million deaths each year. Doxorubicin is a well-known chemotherapy drug which frequently used in treating various types of cancer. However, doxorubicin posesses several side effects including cardiotoxic, hepatotoxic, nephrotoxic, and immunosuppression. One of the natural product that can be used as an adjuvant of doxorubicin to reduce the toxic effects is garlic chives (Allium tuberosum). The purpose of this study was to determine the effect of Allium tuberosum based on hematological profile, levels of CD4+, CD8+, and MDA serum of male Wistar rats which induced by doxorubicin. The hematological profile was analyzes by blood smear, levels of CD4+ and CD8+ were conducted by flowcytometry and levels of MDA serum were determined by spectrofotometry. The results showed that the etanolic extract of Allium tuberosum (EAT) increased neutrophil and lymphocyte, percentage of $\mathrm{CD} 4+$ cells $(p<0.0 \mathrm{I})$ and $\mathrm{CD} 8+$ cells. It also decreased the levels of serum MDA $(p<0.01)$. These results indicated that EAT work as immunostimulant possibly through an antioxidant mechanism (MDA). It can be concluded that EAT can be developed as adjuvant for doxorubicin.
\end{abstract}

Keywords: doxorubicin, Allium tuberosum, immunostimulant, antioxidant, CD4+, CD8+

\section{INTRODUCTION}

Cancer appears as one of the major causes of death in the world. In 2012, there are 14 million new cases and 8.2 million death caused by cancer (WHO, 2015). In Indonesia, the prevalence of cancer in 2013 is $1.4 \%$ and it is predicted that the amount of new case of cancer would be increased up to $70 \%$ in the next two decades (Kemenkes RI, 2015). The high prevalence and mortality of the cancer pushed to developed the effective therapy with the minimum side effect.

Chemotherapy is still considered for treatment in cancer, and one of most frequently used is doxorubicin. Doxorubicin is antibiotic from tetracyclin class which widely used in treating various types of cancer such as breast, pulmonary, prostate, servics, and bone cancer (Li, et al., 2014), however treatment with doxorubicin for long term reveals several side effects including cardiotoxicity, hepatotoxicity, nephrotoxicity and immunosupression (Burridge, et al., 2016; Chaudhary, et al., 2016; Mohebbati, et al., 2016). Doxorubicin suppress the immune system by decreasing the expression level of IL-2, production of the $\gamma$ interferon, natural killer (NK) cells, proliferation of lymphocytes, and rasio CD4+/CD8+ (Zhang, et al., 2005a). The pathway of lipid peroxidase is expected to be one of mechanisms causing oxidative stress from depletion of CD4+ (Gill, et al., 2003). Doxorubicin also increases BUN, creatinin, gout, SGOT, SGPT, and $\gamma$-GT (Roomi, et al., 2014).

Co-chemotherapy is a strategy in cancer therapy by combining a potential compound with chemotherapy agent to increase the efficacy of therapy and also decrease the toxicity of chemotherapy agen (Zhang, et al., 2005b). One of the plants that has potensial is Bawang Kucai (Allium tuberosum). The leaf of bawang kucai contains flavonoids, specifically allicin which is proven to induce immune system by increasing the amount of CD4 (Feng, et al., 2012; Song and Choi, 2016), however the mechanism is still remains unclear.

\footnotetext{
*Corresponding author: ikarahmawati.fk@unej.ac.id
} 
Based on the explanation, Allium tuberosum has prospective potency to be used as co-chemotherapy with doxorubicin. This study is aimed to analyze whether the activity of Allium tuberosum as immunostimulant is through lipid peroxidase in doxorubicin-induced rats.

\section{MATERIALS AND METHODS}

\section{Plants and Extract Preparation}

Bawang kucai (Allium tuberosum) leaves were collected from Malang, Indonesia on March 2016. The leaves were determined by Botanical Laboratory, Faculty of Mathematics and Science, Universitas Jember. Bawang kucai leaves were dried before powdered, resulting in total of 599 grams of kucai leaves powder were extracted by maceration using $70 \%$ ethanol with ratio of $1: 3$. Macerate was filtered using filter paper, then the filtrate was evaporated to collect viscous extract. Bawang kucai extract (BKE) then was administrated to animals in this study.

\section{Animals Preparation}

As many as 37 male Wistar rats weighted 90-150 grams were used in this study. The animals were grouped and housed in cages at temperature and humidity-controlled room (25$32^{\circ} \mathrm{C}$ and $98 \%$ relative humidity) and given free access to food and water. The animals were given time to adapt with laboratory condition for 7 days. The rats then divided into five groups, each groups consisted of 6-7 rats.

\section{In vivo Experimental Design}

Before being treated $\left(\mathrm{D}_{0}\right)$, all rats were adapted for 1 week. The entire groups were given a different treatment for 14 days as follows: 1) Normal control group $(0.9 \% \mathrm{NaCl}$ i.p); 2) Negative control group (4.67 mg/kgBW doxorubicin in $0.5 \%$ CMC-Na p.o); 3) Extract control group $(1000 \mathrm{mg} / \mathrm{kgBW}$ of EAT dissolved in $0.5 \%$ CMC-Na); 4) Treatment A group (4.67 mg/kgBW doxorubicin i.p + 500 $\mathrm{mg} / \mathrm{kgBW}$ BKE p.o); 5) Treatment B group (4.67 $\mathrm{mg} / \mathrm{kgBW}$ doxorubicin i.p +1000 $\mathrm{mg} / \mathrm{kgBW}$ BKE p.o). Doxorubicin induction was done on the day-1 $\left(\mathrm{D}_{1}\right)$ and day-8 $\left(\mathrm{D}_{8}\right)$. All groups were treated daily for 14 days. On 15 th day, the blood were collected from oculary before necropsied to isolate spleen for analysis.

\section{Calculation of White Blood Cells}

Extraction of blood for leukocytes level was collected via oculary venous of all rats on the day-15. White blood cells (leukocytes, lymphocytes and neutrophils) were observed through blood films that smeared on the object glass using microscope 1000x magnification.

\section{The determination of CD4+ and CD8+ concentration}

The percentage of TCD4+ and TCD8+ cells from the spleen were analyzed by flowcytometry. The rats were anasthetized by chloroform before surgery and the spleen was taken. The spleen was put into petri dish filled with $2 \mathrm{~mL}$ of cell staining buffer, then crushed slowly. The cells were moved into a tube and centrifugated in 5 minutes on $5000 \mathrm{rpm}$ and $40^{\circ} \mathrm{C}$, then added with red blood cell lysis buffer and PBS twice. The suspension was stained with FITC anti mouse CD4 and PE anti mouse CD8 in cell staining buffer with ratio $1: 1000$. The data was analyzed by BD FACS Calibur on Cell QuestPro mode.

\section{The determination of MDA Serum Concentration}

Briefly, $100 \mu \mathrm{L}$ blood serum and BHT 10 $\mu \mathrm{L}$ liquid were mixed in glass tube. Consecutively, $700 \mu \mathrm{L}$ orthophosphoric acid 1 $\%$ and $200 \mu \mathrm{L}$ 2-thiobarbituric acid (TBA) $0.6 \%$ were added in tube then incubated into waterbath filled by hot water $95^{\circ} \mathrm{C}$ for 45 minutes. After incubation, the tube was chilled in the cold water. $1 \mu \mathrm{L}$ n-butanol was added into tube, then centrifugated in $2000 \mathrm{rpm}$ for 10 minutes. The top layer was taken and the absorbance was determined by spectrophotometer in $\lambda 535 \mathrm{~nm}$. TBARS (Thiobarbituric Acid Reactive Substance) is a MDA bioproduct that condensed with TBA, calculated in $\mu \mathrm{M}$ using coefficient extinction 1 , $56 \times 105 \mathrm{M}^{-1} \mathrm{~cm}^{-}$.

\section{RESULT AND DISCUSSION}

\section{Thin Layer Chromatography Profile}

The TLC system consist of silica F254 as stationary phase and butanol, acetic acid, dan aquadest $(8: 2: 10)$ as mobile phase. The result showed EAT contain flavonoid as its compound (Fig. 1). 


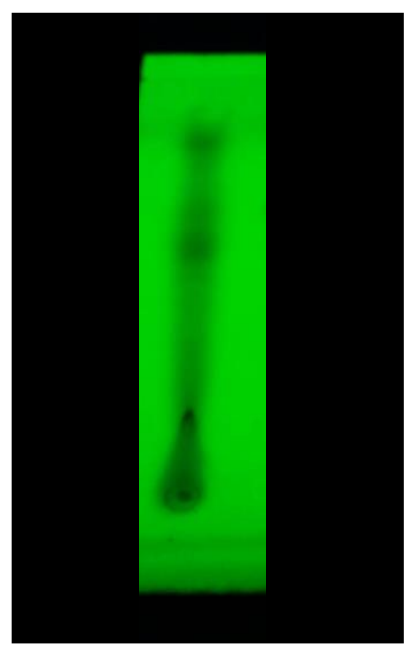

Figure I . Result of EAT TLC's Test

\section{Effect EAT on Hematologic Profile (Lymphocyte and Neutrophil)}

Intraperitoneal administration of doxorubicin could reduce the percentage of lymphocytes compare with control group, but did not affect the percentage of neutrophils (Table 1). Meanwhile, EAT treatment against Doxorubicin-induced group could increase the percentage of lymphocytes and neutrophiles. Based on the dose given, EAT $500 \mathrm{mg} / \mathrm{kgBB}$ is better in increasing lymphocytes percentages, while EAT $1000 \mathrm{mg} / \mathrm{kgBB}$ is better in increasing the neutrophiles percentages.

\section{Effect EAT againts CD4 + and CD8 + cells}

Potency of EAT as immunostimulant also confirmed by analysis flowcytometri about the percentage of CD4+ and CD8+ (Fig. 2). Treatment of EAT on doxorubicin induced group showed an increase in CD4+ cells were significantly $(p<0.01)$ compared to those induced doxorubicin alone, either at a dose of 500 or $1000 \mathrm{mg} / \mathrm{kg}$ (Table 1). The combination also able to increase the percentage of CD8+ cells.

Table I. Effect of EAT on levels of lymphocytes, neutrophils, the percentage of CD4+, CD8+, and the ratio of CD4+ / CD8+

\begin{tabular}{lccccc}
\hline \multicolumn{1}{c}{ Group } & $\begin{array}{c}\text { lymphocytes } \\
(\%)\end{array}$ & $\begin{array}{c}\text { neutrophils } \\
(\%)\end{array}$ & CD4+ (\%) & CD8+ (\%) & $\begin{array}{c}\text { Ratio } \\
\text { CD4+/CD8+ }\end{array}$ \\
\hline Control & $37.20 \pm 7.46$ & $40.60 \pm 11.52$ & $20.13 \pm 6.46$ & $14.81 \pm 2.18$ & $1.43 \pm 0.64$ \\
DOX & $30.80 \pm 6.18$ & $40.20 \pm 6.38$ & $11.73 \pm 1.02$ & $12.72 \pm 2.53$ & $0.96 \pm 0.27 \mathrm{a}$ \\
EAT 1000 & $45.60 \pm 3.51$ & $49.00 \pm 5.70$ & $35.65 \pm 1.93 \mathrm{a}$ & $17.15 \pm 6.44$ & $2.48 \pm 0.41$ \\
DOX + EAT 500 & $41.40 \pm 6.73$ & $45.40 \pm 6.95$ & $22.95 \pm 6.09 \mathrm{~b}$ & $15.79 \pm 12.93$ & $1.47 \pm 0.18$ \\
DOX + EAT 1000 & $38.48 \pm 7.30$ & $48.40 \pm 9.24$ & $28.69 \pm 4.65 \mathrm{~b}$ & $17.61 \pm 2.29$ & $1.66 \pm 0.43$ \\
\hline
\end{tabular}

a $p<0,01$ dibandingkan dengan Control group

b $p<0,05$ dibandingkan dengan DOX group. 


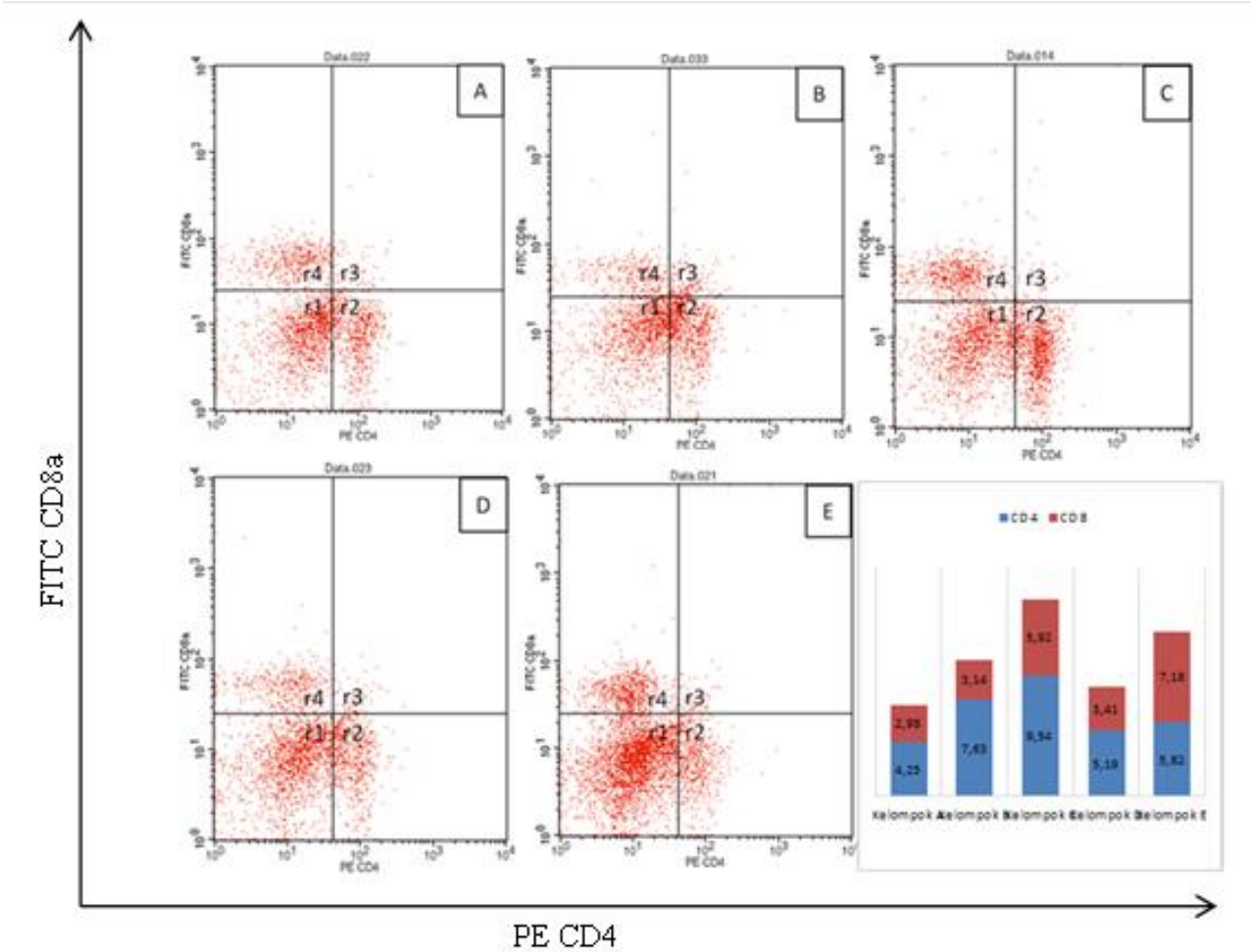

Figure 2. Effect ethanolic extract of Allium tuberosum (EAT) against the percentage of CD4 and CD8's male Wistar rats. The histogram shows the distribution of CD4+ T cells ( $r 2)$ and the distribution of CD8+ cells (r4) on : (A) Normal Control without treatment, (B) doxorubicin, (C) EAT Controls $1000 \mathrm{mg} / \mathrm{kg}$, (D) A combination of doxorubicin and EAT $500 \mathrm{mg} / \mathrm{kg}$, and (E) A combination of doxorubicin and EAT $1000 \mathrm{mg} / \mathrm{kg}$.

\subsection{Effect of EAT Againts MDA serum levels}

To confirm the repair mechanism of immune system pathways were measured MDA levels. MDA is used as an indicator of an reorganize by lipid peroxidation. MDA increased indicate oxidation processes or membrane damage caused by free radicals. Fig. 3 shows the doxorubicin increase the MDA serum levels were significantly $(p<0.01)$. Meanwhile, EAT administration after induction by Doxorubicin can lower MDA serum levels were significantly $(p<0.05$ at a dose of $500 \mathrm{mg} / \mathrm{kg}$ and $\mathrm{p}<0.01$ at a dose of $1000 \mathrm{mg} / \mathrm{kg}$ body weight). 


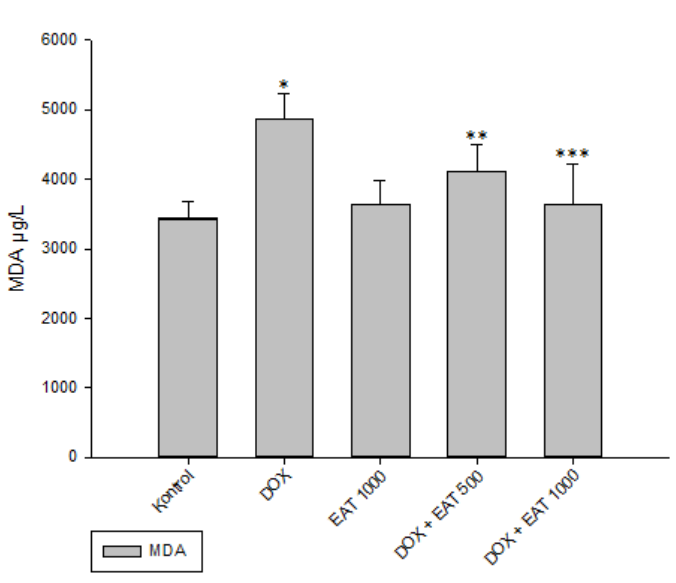

Information:

*) $p<0.0$ l compared with control group ** ) $p<0.05$ compared with DOX group

$* * *$ ) $p<0.01$ compared with DOX group

Figure 3. Effect of EAT on MDA serum levels

Doxorubicin had chemotherapeutic effect that classified as an anthracycline class. The chemotherapeutic agents most often chosen and most effective since 1970 (Alessandra, et $a l .$, 2007). Doxorubicin is used for the various types of cancer such as breast, lung, prostate, cervical, bone, etc. (Li, et al., 2014). Doxorubicin is not selective, it is affect not only cancer cells but also normal cells that divide actively. As a result of the non-selective affect, doxorubicin also affect the formation of cells that are actively dividing cells such as bone marrow, lymphocytes, hair, and various organ toxicities (Tacar, et al., 2012).

In this study, EAT restore immune function previously suppressed by doxorubicin. Induction doxorubicin dose $4.67 \mathrm{mg} / \mathrm{kg}$ on the first day and 8 show a significant effect in reducing the immune cells, it is accordance with the results of the study (2011). In the previous studies, doxorubicin induction on the first day and the fourth day, the treatment give a significan effect to reduction CD4+. While the immunostimulatory effect of EAT indicated by an increased proliferation of lymphocytes, neutrophils and increased CD8+ cytotoxic Tcells and CD4+ T helper cells, this effect is due to the flavonoid on EAT. Flavonoids are able to increase the number of $\mathrm{CD} 4+$ significantly according research Chauhan, et al. (2010). In contrast to this, in this study EAT increase CD8+ but not significant because of the content of other compounds that are immunosuppressive in EAT as steroids or terpenoids (Zhang, et al., 2009).

MDA levels measurement was conducted to confirm mechanism of action of EAT as immunostimulant. MDA was used as an indicator of a recast by lipid peroxidation. The effects of doxorubicin toxicity possible due to oxidative stress. This study shows that the induction of doxorubicin significantly increases serum MDA levels. After EAT administration, MDA decreased which indicated lipid peroksidase pathway played a role in the mechanism of immunosuppression.

Based on the data, we can conclude that doxorubicin causes immunosuppression. EAT at the dose of $1000 \mathrm{mg} / \mathrm{kg}$ after induction of doxorubicin able to restore the immune system significantly by increased antioxidant activity.

\section{REFERENCES}

Alessandra, L., Stefano, F., Gaetano, B.and Salvatore S., 2007., Long-term FollowUp of Patients with Doxorubicininduced Cardiac Toxicity After Chemotherapy for Osteosarcoma, Anti Cancer Drugs, I 8(6), 737-744.

Chaudhary, D., Khatiwada, S., Sah, S.K.,Tamang M.K., Bhattacharya S. and Jha C.B., 2016, Effect of Doxorubicin on Histomorphology of Liver of Wistar Albino Rats, J. Pharm. Pharmacol., 4(2016), $186-190$.

Chirumbolo, S., 2010, The Role of Quercetin, Flavonols and Flavones in Modulating Inflammatory Cell Function, Inflamm. Allergy Drug Targets, 9(4), 263-85.

Feng, Y., Zhu, X., Wang, Q., Jiang, Y., Shang, $\mathrm{H}$., $\mathrm{Cu}$, L., et al., 20I2, Allicin Enhances Host Pro-inflammatory Immune Responses and Protects Against Acute murine malaria infection, Malar. J., I I (I), 268-276. 
Gill, L., Martinez, G., Gonzalez, I., Tarinas,A., Alvarez, A., Giuliani, A., et al., 2003. Contribution to Characterization of Oxidative Stress in HIV/AIDS Patients, Pharmacol. Res., 47(3), 2 I 7-224.

Kasianningsih, S., Rivanti, E., Pratama, R.H.,Pratama, N.R., Ikawati, M. and Meiyanto, E., 20II., Taraxacum officinale Leaves Etanolikic Extract as Immunostimulatory Agent for Reducing Side Effect of Doxorubicin in Sprague Dawley Rats, Indones. J. of Cancer Chemoprevent., 2(I), I35-140.

Kementrian Kesehatan RI, 20I5, SituasiPenyakit Kanker, Jakarta: Pusatdata dan informasi Kementrian Kesehatan RI.

Li. M., Tang, Z., Lv, S., Song, W., Hong, H.,Jing, X., et al., 20I4, Cisplatin Crosslinked $\mathrm{pH}$ Sensitive Nanoparticles for Efficient Deliveryof Doxorubicin, Biomaterials, 35(I2), 385 I-3864.

Mohebbati, R., Abbsnezhad, A., Khajavi,R.A., Mousavi, S.M. and Haghshenas M., 2016, Effect of HydroalcholicExtract of Nigella sativa on Doxorubicin-Induced Functional Damage of Kidney in Rats, Horizon Med. Sci., 22(I), I3-20.

Roomi, W., Kalinovsky, T., Roomi, N.W.,Rath, W. and Niedzwiecki, A., 2014, Prevention of Adriamycin-induced Hepatic and Renal Toxicity in Male BALB/c Mice by a Nutrient Mixture, Exp. Ther. Med., 7(4), I040-1044.
Song, W.Y. and Choi J.H., 2016, Effects of Oenanthe javanica and Allium tuberosum on Lipid Content in Rats Fed a High-fat High-cholesterol Diet, J. Life Sci., 26(3), 302-308.

Tacar, O., Sriamornsak, P. and Dass, C.R., 2012, Doxorubicin: An Update onAnticancer Molecular Action, Toxicityand Novel Drug Delivery Systems, J. Pharm. Pharmacol., 65(2), I57170.

World Health Organization, 2015, Cancer, http://www.who.int/mediacentre/factshe ets/fs297/en/, Cited June 8, 2016.

Zhang, F., Zhang, X., Wang, B.C. and Wang,F., 2009, Pachymic Acid, A Novel Compound for Anti-Rejection: Effect in Rats Following Cardiac Allograft Transplantation, Chin. Med. J., I 22(23), 2898-2902.

Zhang, X., Li, W., Wu, Y., Zheng, T., Li, W.,Qu, S., et al., 2005b, Proanthocyanidin from Grape Seeds Potentiates Anti-tumor Activity of Doxorubicin via Immunomodulatory Mechanism, Int. Immunopharmacol., 5(78), I247-I 257.

Zhang, X.Y., Li, W.G., Wu, Y.J. and Gao, M.T., 2005a, Amelioration of DoxorubicinInduced Myocardial Oxidative Stress and Immuosuppression by Grape Seed Proanthocyanidins in Tumour-bearing Mice, J. Pharm. Pharmacol., 57(8), I043I05I. 